\title{
SERVICE QuALITY PERCEPTIONS \\ IN THE BANKING INDUSTRY: MAJOR DIMENSIONS
}

\author{
Minjoon Jun \\ New Mexico State University \\ Las Cruces, NM \\ Robin T. Peterson \\ New Mexico State University \\ Las Cruces, NM \\ George A. Zsidisin \\ Arizona State University \\ Tempe, AZ \\ Bonnie F. Daily \\ New Mexico State University \\ Las Cruces, NM
}

\begin{abstract}
This article aimed to expand the body of knowledge relating to the issues associated with customer-focused service quality and effective service delivery. A mail questionnaire inquired into the effectiveness of the marketing and operations functions of commercial banks in delivering loan products. This study revealed that substantial differences existed between bankers and customers groups in the perceived importance of service quality dimensions. Some suggestions and recommendations were provided to close the "gaps" and improve banking service quality.
\end{abstract}

\section{Introduction}

During the past decade, the banking industry has witnessed a number of dramatic changes. The deregulation of the financial sector in 1982 has paved the way for free market entry and has enabled banks to pay what they want in interestbearing accounts and assess desired charges for the services. Essentially, deregulation has intensified rivalry among banks in the U.S. and abroad and has led to increased competition from nontraditional institutions such as money management, securities, and insurance companies. In addition, new information technologies, such as check imaging, home banking, and electronic funds transfer, have sped and simplified financial activities and eroded geographic boundaries, producing further volatility in the industry.

This unprecedented competitive market environment presents bankers with substantial marketing and operations challenges. Many bankers have arrived at 
the conclusion that effective quality management practices can enhance their competitive advantage in this rival-driven marketplace, and have embraced Total Quality Management (TQM) or TQM-type programs over the past decade (Rivers, 1993; Boaden \& Dale, 1993). If properly implemented, TQM can result in enhanced levels of service quality, reduced operating costs, the creation and retention of loyal customers through response to changing customer needs, and thus improved financial results (e.g., Easton \& Jarrell, 1998; Hendricks \& Singhal, 1997; and Flynn et al., 1995). One bank, for example, increased its profitability, directly due to a TQM initiative, by over two million dollars annually in a period of under two years (Bird, 1993). However, TQM has resulted in a mixed success record, although banks have expended considerable time and effort, and have devoted substantial financial resources on quality tools and training and the launching of quality improvement teams (Tucci, 1997; Eskildson, 1995).

Many researchers (Amsden et al., 1996; Hakserver, 1996; Cowling \& Newman, 1995; and Dotchin \& Oakland, 1994, to name a few) have attempted to identify the key elements of an effective TQM program and those identified can be summarized as: customer-driven quality, continuous improvement, top management leadership, teamwork, employee empowerment, and involvement of multiple personnel in decision making. Customer-focused quality management is one of the most important TQM ingredients and is a point of departure for the implementation of such initiatives (Amsden et al., 1996; Lengnick-Hall, 1996; Reed et al., 1996; and Dean \& Bowen, 1994). This is the case because the customer is the ultimate judge of product quality. If a company fails to identify precisely what customers want and to closely monitor their changing preferences, efforts to provide satisfaction are likely to be ineffective.

This article aims to expand the body of knowledge relating to the issues associated with customer-focused service quality and effective service delivery by examining the following questions: (1) What do bank customers perceive to be the key attributes of quality?; (2) What do bank executives and loan officers perceive to be the key attributes of quality?; (3) Are there substantial discrepancies between bankers and customers in the perceived importance of the determinants of service quality?; and (4) If any discrepancies exist between these two groups, what can be recommended to close the "gaps" and hence to permit improvements in service quality? Such an examination is essentially pertinent, given governmental commitment and support to quality initiatives and the range of companies which are currently embarking on programs of product and process quality improvement.

\section{Research Objectives}

This study investigated the effectiveness of the marketing and the operations functions of commercial banks in delivering two loan products: commercial and installment loans. This was accomplished by searching for possible dissimilarities between customers and bankers in the perceived importance of service qual- 
ity dimensions. Loan services were selected for this study since they are the most important profit generation source in community banking.

Specifically, the research first identified and prioritized the bank service quality attributes for the two types of loan products, as perceived by the two groups: bankers (executives and loan officers) and customers. Second, the study investigated discrepancies between the banker and customer groups with regard to the perceived importance of the quality attributes for the loan products. Third, when significant differences between the two groups was observed, this research examined the perceived "gaps" in importance of each of the 19 service quality attributes. Finally, this study provided various recommendations that may assist service providers in closing the "gaps" and improving the quality level of loan services.

\section{Literature Review}

\section{Strategic Importance of Customer Focused Service Quality}

The managers of many service firms have concluded that quality is one of the major underlying contributors to their success (Mefford, 1993). According to Shetty (1987), the attainment of quality can advance profitability by reducing costs and enhancing the firm's competitive position in the marketplace. Consumers are increasingly becoming more quality conscious (Moore \& Schlegelmilch, 1994). Hence, it is imperative that service firms not only satisfy customers but also delight them (Saunders, et al., 1995). "Delighted" customers are those whose expectations have not just been met, but have been exceeded (Berry, Parasuraman, \& Zeithaml, 1988).

Recent studies have shown that high levels of service quality can exert a positive influence on customer satisfaction (Cronin \& Taylor, 1992; Parasuraman, Zeithaml, \& Berry, 1988). This force is so far-reaching that among the various criteria of the 1997 Malcolm Baldrige National Quality Award, three dimensions including customer and market knowledge, customer satisfaction and relationship enhancement, and customer satisfaction results accounted for 210 out of 1,000 total points. Significantly, TQM programs focus on the importance of customer satisfaction through the provision of high quality products and services.

\section{Identification and Measurement of Service Quality}

Unlike a manufactured product where quality can be readily assessed, based on product specifications, service quality has no direct and tangible criteria for measurement. That is, service quality is an elusive and abstract construct that poses definition and measurement obstacles. Ross (1995) has proposed a customer-focused quality assessment effort. He has noted that services are not actions and behaviors in and of themselves, but are the means whereby customers perceive and interpret those actions. Of course, the inherently subjective nature of service quality makes the measurement task complex. The banking industry is 
no exception in relation to the problems of complexity and efficacy in the conceptualization and measurement of service quality.

The complexity of measuring banking service quality is evident through an examination of three well-documented features of services: intangibility, heterogeneity, and inseparability of production and consumption (Parasuraman, Zeithaml, \& Berry, 1985). First, services are intangible, as it is not possible to count, measure, inventory, test or verify them in advance of delivery. Most banking services, such as loan processing, cannot be stored and their quality assessed in advance. Customer experience, either directly or vicariously from outside sources, is frequently the only means of verifying whether bank services manifest high quality. Second, service performance diverges from transaction to transaction. This heterogeneity can occur because the service is delivered at various times, by different employees to a variety of customers with varying needs. Finally, in banking services, production and consumption are inseparable. The services are consumed when they are produced, which renders quality control difficult (DeSouza, 1989). This condition necessitates that marketing and operations functions occur simultaneously (Mefford, 1993).

In spite of these obstacles, customer perceptions of service quality should be assessed in all banks. This is the case since it is difficult to manage and improve that which is not carefully defined and measured. Compared with other service industries such as healthcare, little literature has addressed in depth the issues of identifying bank service quality attributes and measuring customer satisfaction. Most past studies have focused either (1) on anecdotal cases about banks' quality improvement efforts in which a few of key service quality dimensions were briefly discussed or (2) on a conceptual framework for TQM approaches and identifying causes of failures. Customer satisfaction is an outcome of a range of quality attributes which include the quality of service core products (i.e., interest rate, fees) and of service delivery (i.e., error rate, process time, accessibility of service and equipment failures). More specifically, customer satisfaction occurs when customers feel that the overall quality of service products and delivery of service has met or exceeded their expectations relative to the competition and the cost they have paid.

Gronroos $(1984,1983)$ has noted that perceived service quality is influenced by both a technical and a functional dimension. Technical quality is the material content of the buyer-seller interaction: what the customer receives. This dimension would include error rates, process times, accessibility of services, and equipment failures. On the other hand, the functional quality is the manner in which this technical quality is transferred: how the customer receives a service. This dimension would include the responsiveness, competence and courtesy displayed in the delivery of the service. These two dimensions of quality combine to form a perceptual map in the mind of the customer.

Parasuraman, Zeithaml, and Berry (1985) have attempted to identify those dimensions that customers employ when evaluating services, in terms of anticipated expectations. Their objective was to discover those dimensions that were generic and relevant to services in general. Parasuraman et al. (1985) initially 
identified ten determinants of service quality, based on a series of focus group sessions. These were tangibles, reliability, responsiveness, competency, courtesy, communication, credibility, security, access, and understanding. Later Parasuraman et al. (1988) developed SERVQUAL, an instrument created to measure five service quality dimensions including tangibles, reliability, responsiveness, assurance, and empathy, which were distilled from ten original determinants using factor analysis. This method has been adopted by many banks to assess service quality (Cowling \& Newman, 1995). For example, one bank used the five quality dimensions and found that the disparity between expectations and perceptions were the highest for reliability, responsiveness, and empathy, and the lowest on tangibles. However, these dimensions developed by Parasuraman et al. (1988) have received some criticism, although they have been frequently used in the field of service quality management (Johnston, 1995). For instance, Cronin and Taylor (1992), in their research into service quality in banks, pest control, dry cleaning, and fast food, found that the five-dimension structure for the SERVQUAL scale was not confirmed in any of their samples.

Armistead (1990) has suggested that the key determinants of service quality are categorized into two categories: firm and soft groups. The firm group includes time (i.e., availability, waiting time and responsiveness), fault freeness (i.e., physical items, information and advice), and flexibility (i.e., ability to recover from mistakes, to customize the service or add additional services). In return, the soft group comprises style (i.e., attitude of staff, accessibility of staff and ambience), steering (i.e., the degree to which customers feel in control of their own destiny), and safety (i.e., trust, security, and confidentiality).

Johnston (1995) has attempted to classify the determinants of service quality into those which are predominantly satisfiers and others that are predominantly dissatisfiers, using the critical incident technique. He selected a bank for his study because banks have identifiable customers, many of whom will have undertaken not just a single experience with that organization, but an ongoing relationship over a period of time, involving multiple transactions. Johnson (1995) identified 18 individual determinants of service quality. They include access, aesthetics, attentiveness/helpfulness, availability, care, cleanliness/tidiness, comfort, commitment, communication, competence, courtesy, flexibility, friendliness, functionality, integrity, reliability, responsiveness, and security.

In assessing the intangible segment of bank branch operations, Athanassopoulous (1997) employed three quality dimensions: physical, corporate, and interactive quality. The first, physical quality incorporates the physical aspects of the service (i.e., equipment, buildings, other tangibles). Corporate quality includes dimensions related to the corporate image of bank branches' the parent organization. Finally, interactive quality embraces the nature of the direct interaction between the customers and the bank service delivery mechanisms including personal involvement (i.e., credit/debit transactions) and mechanical involvement (i.e., ATM transaction): 
In order to accomplish the research objectives of this study, the authors identified a total of 19 key quality attributes of loan services, rather than quality dimensions of general banking service, through a content analysis of the relevant literature discussed earlier and interviews with practitioners. These attributes are total cost of loan, interest rate, amount of security, choice of loan duration, points (front end fees), total number of payments, competence of loan officers, credibility, amount of required documentation, relationship banking, courteous service, location of loan approval authority, loan processing time, responsiveness to customers, reliable service, communications, appearances, high traffic and accessible location, and physical layout. The discussion that follows outlines the procedures which were included in the analysis.

\section{Methodology}

A mail survey was employed to elicit information regarding the perceptions of bankers and loan customers. The survey questionnaires were initially developed by the researchers, based upon previous studies and then were reviewed by two practitioners from the banking industry. Various alterations were undertaken, based on their inputs. In turn, survey questionnaires were forwarded to the bank executives and loan officers. In the cover letter, the bankers were requested to distribute the survey questionnaires to the customers of commercial and installment loans, who were either recent loan applicants or recipients.

A total of 500 questionnaires were mailed to a sample of 25 banks located in the southwestern region of the U.S. and 124 usable returns were obtained, resulting in a response rate of $24.8 \%$. Table 1 summarizes the number of usable returns classified by loan types, and by banker and customer groupings.

Table 1

Mail Survey Responses By Loan Types and By Customer and Banker Groups

\begin{tabular}{llcl}
\hline & Installment Loan & Commercial Loan & Total \\
\hline Bankers & 31 & 32 & $63(50.8 \%)$ \\
Customers & 39 & 22 & $61(49.2 \%)$ \\
Total & $70(56.5 \%)$ & $54(43.5 \%)$ & $124(100 \%)$ \\
\hline
\end{tabular}

A total of 19 key quality attributes of loan services that were mentioned in the literature review section were identified by the authors. These attributes were categorized into two categories: loan product characteristics, and processing and delivery of loan service. The definitions of these attributes appear in Table 2. 
Table 2

Service Quality Dimensions of Loan Products

\section{Loan Product Characteristics:}

1. Total Cost of Loan (principal, interest, fees).

2. Interest Rate (equivalent APR).

3. Amount of Security (deposits, assets, down payment).

4. Choice of Loan Duration.

5. Points, front end fees.

6. Total Number of Payments.

\section{Processing and Delivery of Loan Service:}

7. Competence of Loan Officers, skilled and knowledgeable.

8. Credibility, Trustworthiness, Honesty of Bank Personnel.

9. Amount of Required Documentation (minimum paperwork)

10. Relationship Banking: non-intimidating, behavior towards customer, seeking long term banking relationships.

11. Courteous Service: polite, respect, friendly.

12. Location of Loan Approval Authority: centralized, decentralized, or other.

13. Loan Processing Time: time needed to get approval.

14. Responsiveness to Customers: prompt problem solving and other customerrequested assistance.

15. Reliable Service: consistent error free service.

16. Communications: informing customers clearly and completely free from loan application to end of loan.

17. Appearances: grounds, furnishing, personnel.

18. High Traffic and Accessible Location.

19. Physical Layout: access to parking, loan office privacy.

In the questionnaire, the bankers were asked to rate each of the 19 service quality attributes in terms of their capability to attract and retain eligible loan customers. In turn, the customers were asked to rate each of the attributes in regard to their perceived importance in evaluating the quality of loan services. A Likert-type seven-point scale ranging from $1=$ no importance to $7=$ exireme importance was utilized for these measurements.

\section{Results and Discussions}

\section{Perceived Importance of Each Dimension}

Tables 3 and 4 summarize the mean scores, standard deviations, and rankings of each of the 19 quality attributes, classified by customers and bankers groups, for installment and commercial loans respectively. As is indicated in Table 3, for both respondent groups, all of the quality dimensions for installment loans have mean score of 4.4 or higher. This suggests that the members of both customer and 
banker groups perceive all of the dimensions listed to lie between "important" and "extremely important" as gauges of service quality for installment loans. In addition, both the customer and the banker groups produced an identical rank order of the top five attributes, including, in order of importance, credibility, courteous service, competence, responsive to customers, and reliable service. Further all five dimensions have a mean score of 6.0 (= of great importance) or higher. However, in the case of the customer group, five additional dimensions yielded a mean score of 6.0 or higher: relationship banking, interest rate, communications, total cost of loan, and loan processing time. This suggests that customers for installment loans are expecting higher service quality levels on a wider range of quality attributes than are bankers.

Table 3

Installment Loans

(Customers Group)

\begin{tabular}{llcc}
\hline Quality Attributes & M† & SD†† & Rank \\
\hline Credibility & $6.6^{*}$ & 0.7 & 1 \\
Courteous Service & 6.6 & 0.6 & 1 \\
Competence of Loan Officers & 6.5 & 0.6 & 3 \\
Responsiveness to Customers & 6.5 & 0.7 & 3 \\
Reliable Service & 6.5 & 0.7 & 3 \\
Relationship Banking & 6.4 & 1.0 & 6 \\
Interest Rate & 6.3 & 1.1 & 7 \\
Communications & 6.3 & 1.1 & 7 \\
Total Cost of Loan & 6.3 & 1.1 & 7 \\
Loan Processing Time & 6.1 & 1.0 & 10 \\
\hline Choice of Loan Duration & 5.9 & 1.1 & 11 \\
Points, Front End Fees & 5.7 & 1.4 & 12 \\
Amount of Securities & 5.5 & 1.4 & 13 \\
Amount of Required Documentation & 5.4 & 1.3 & 14 \\
\# of Payments & 5.4 & 1.4 & 14 \\
Location of Loan Approval Authority & 5.2 & 1.6 & 16 \\
High Traffic and Access Location & 5.1 & 1.3 & 17 \\
Physical Layout & 5.1 & 1.3 & 17 \\
Appearances & 5.0 & 1.4 & 19 \\
\hline
\end{tabular}

Note: $\quad+$ Mean

$+\dagger$ : Standard Deviation

* : A Likert-type seven-point scale

( $1=$ No Importance; $4=$ Moderate Importance; $7=$ Extreme Importance) 
Table 3 (continued)

Installment Loans

(Bankers Group)

\begin{tabular}{llcc}
\hline Quality Attributes & M $\dagger$ & SD $+\dagger$ & Rank \\
\hline Credibility & $6.4^{*}$ & 0.9 & 1 \\
Courteous Service & 6.3 & 0.8 & 2 \\
Competence of Loan Officers & 6.1 & 1.0 & 3 \\
Responsiveness to Customers & 6.1 & 1.0 & 3 \\
Reliable Service & 6.0 & 1.1 & 5 \\
\hline Communications & 5.8 & 1.2 & 6 \\
Loan Processing Time & 5.5 & 0.9 & 7 \\
Relationship Banking & 5.5 & 1.2 & 7 \\
Total Cost of Loan & 5.2 & 1.3 & 9 \\
Appearances & 5.1 & 1.3 & 10 \\
Location of Loan Approval Authority & 5.0 & 1.5 & 11 \\
Amount of Securities & 5.0 & 1.2 & 11 \\
High Traffic and Access Location & 5.0 & 1.2 & 11 \\
\hline Interest Rate & 4.9 & 0.9 & 14 \\
Points, Front End Fees & 4.8 & 1.1 & 15 \\
Choice of Loan Duration & 4.7 & 1.0 & 16 \\
\# of Payments & 4.6 & 1.0 & 17 \\
Amount of Required Documentation & 4.5 & 1.1 & 18 \\
Physical Layout & 4.4 & 1.3 & 19 \\
\hline
\end{tabular}

Note: $\quad \uparrow:$ Mean

f†: Standard Deviation

* : A Likert-type seven-point scale

( $1=$ No Importance; $4=$ Moderate Importance; $7=$ Extreme Importance $)$

As shown in Table 4, for commercial loans, the dimensions of high traffic and access location, number of payments, and physical layout were positioned by both of the responding groups as between "not important" and "neutral," and the dimension of appearances was also specified as "not important" by the customer group. The remainder of the dimensions manifest a mean score of 4.1 or higher, for both of the two groups. The customer group ranked credibility, competence, relationship banking, reliable service, and total cost of loan as the top five dimensions, whereas bankers considered credibility, competence, responsiveness to customers, courteous service, and reliable service as the most important. Further, all the mean scores of the top five dimensions for the customer group are higher than or equal to 6.0, while only one dimension, credibility, has a mean score of higher than 6.0 for the banker group. This configuration suggests that bankers should focus increased attention on such dimensions as relationship banking and total cost of loan. 
Table 4

\section{Commercial Loans}

\begin{tabular}{|c|c|c|c|}
\hline Quality Attributes & $\mathbf{M}+$ & SDtt & Rank \\
\hline \multicolumn{4}{|c|}{ (Customers Group) } \\
\hline Credibility & $6.7^{*}$ & 0.6 & 1 \\
\hline Competence of Loan Officers & 6.6 & 0.8 & 2 \\
\hline Relationship Banking & 6.0 & 1.2 & 3 \\
\hline Reliable Service & 6.0 & 0.9 & 3 \\
\hline Total Cost of Loan & 6.0 & 1.5 & 3 \\
\hline Responsiveness to Customers & 5.8 & 1.2 & 6 \\
\hline Courteous Service & 5.8 & 1.2 & 6 \\
\hline Points, Front End Fees & 5.7 & 1.6 & 8 \\
\hline Interest Rate & 5.6 & 1.3 & 9 \\
\hline Loan Processing Time & 5.6 & 1.0 & 9 \\
\hline Location of Loan Approval Authority & 5.4 & 1.5 & 11 \\
\hline Arnount of Securities & 5.2 & 1.6 & 12 \\
\hline Amount of Required Documentation & 5.2 & 1.1 & 12 \\
\hline Communications & 5.2 & 1.5 & 12 \\
\hline Choice of Loan Duration & 5.1 & 1.2 & 15 \\
\hline High Traffic and Access Location & 3.9 & 1.6 & 16 \\
\hline \# of Payments & 3.7 & 1.8 & 17 \\
\hline Appearances & 3.6 & 1.8 & 17 \\
\hline Physical Layout & 3.5 & 1.7 & 18 \\
\hline \multicolumn{4}{|c|}{ (Bankers Group) } \\
\hline Credibility & $6.1^{*}$ & 1.2 & 1 \\
\hline Competence of Loan Officers & 5.9 & 1.0 & 2 \\
\hline Responsiveness to Customers & 5.8 & 1.2 & 3 \\
\hline Courteous Service & 5.8 & 1.2 & 3 \\
\hline Reliable Service & 5.7 & 0.9 & 5 \\
\hline Relationship Banking & 5.7 & 1.2 & 5 \\
\hline Communications & 5.6 & 0.8 & 7 \\
\hline Loan Processing Time & 5.2 & 0.7 & 8 \\
\hline Interest Rate & 5.1 & 1.0 & 9 \\
\hline Total Cost of Loan & 5.0 & 1.0 & 10 \\
\hline Amount of Securities & 4.9 & 0.9 & 11 \\
\hline Choice of Loan Duration & 4.6 & 1.0 & 12 \\
\hline Points, Front End Fees & 4.6 & 1.0 & 12 \\
\hline Amount of Required Documentation & 4.5 & 1.3 & 14 \\
\hline Location of Loan Approval Authority & 4.5 & 1.2 & 14 \\
\hline Appearances & 4.1 & 1.4 & 16 \\
\hline \# of Payments & 3.9 & 1.1 & 17 \\
\hline High Traffic and Access Location & 3.8 & 1.1 & 18 \\
\hline Physical Layout & 3.8 & 1.1 & 18 \\
\hline
\end{tabular}

Note: $t:$ Mean

$\uparrow \uparrow:$ Standard Deviation

*: A Likert-type seven-point scale

( $l=$ No Importance; $4=$ Moderate Importance; $7=$ Extreme Importance) 
In addition, for each of the product types, both the customer and the banker groups tend to focus on the dimensions in the processing and delivery category of loan service more than those in the product characteristics category. Given that new products developed by a bank can be quickly and easily imitated by its competitors, using the definitions of Gronroos $(1984,1983)$, functional quality (i.e., how the customer receives a service) may be a more useful source for gaining a sustainable competitive advantage over competitors than technical quality (i.e., what the customer receives).

\section{Between Group Agreement}

The between group agreement for the two segments in the sample was assessed through Multivariate Analysis of Variance (MANOVA). As shown in Table 5, both of the two MANOVA tests reject the null hypothesis that the two groups have equal means on the 19 service quality dimensions (for installment loans, $F=3.43177$ with a $p$ value of 0.000 ; for commercial loans, $F=3.40902$ with a $p$ value of 0.001 ). In other words, for both types of loan products, there is a highly significant disagreement among the two groups in perceiving the relative importance of the quality dimensions.

\section{Gap Measurement Between Groups for Each Dimension}

In order to detect dissimilarities between the two groups with respect to each of the 19 service quality dimensions for the two loan product types, two-tailed ttests for equality of means were employed at the p<.05 level. This was undertaken to identify gaps between customers and bankers for the two loan products in their perceptions of the importance of each dimension. Table 6 presents the mean scores and standard deviations for the customer and banker groups in the first two columns, and t-values and p-values in the last two columns. As indicated in the Table, for installment loans, twelve dimensions were significantly different in the perceived importance by the two groups, whereas for commercial loans, only three attributes were perceived to be significantly different.

Table 5

Between Group Agreement Measured By Multivariate Analysis of Variance

\begin{tabular}{lccc}
\hline Loan Types & Wilks' Lambda & F value & P-value \\
\hline Installment Loans & .39998 & 3.43177 & .000 \\
Commercial Loans & .30891 & 3.40902 & .001 \\
\hline
\end{tabular}


Table 6

Gap Measurement Between Two Groups Measured By T-test

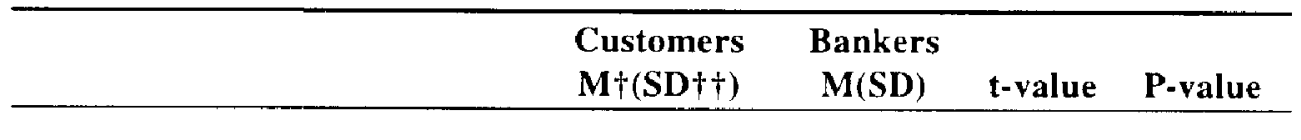

Installment Loan

Competence of Loan Officers

$6.5(0.6)$

$6.1(1.0)$

2.06

$.044^{*}$

Amount of Required Documentation

$5.4(1.3)$

$4.5(1.1)$

2.94

$.005^{* * *}$

Interest Rate

$6.3(1.1)$

$4.9(0.9)$

5.63

$.000 * * * *$

Choice of Loan Duration

$5.9(1.1)$

$4.7(1.0)$

4.66

$6.4(1.0)$

$5.5(1.2)$

$.000^{* * * *}$

Relationship Banking

$6.6(0.6)$

$6.3(0.8)$

3.45

$6.1(1.0)$

$5.5(0.9)$

2.22

$.001 * * * *$

Loan Processing Time

$6.5(0.7)$

$6.1(1.0)$

2.85

$.030 *$

Responsive to Customers

$6.5(0.7)$

$6.0(1.1)$

2.31

$.006 * *$

Reliable Service

$5.4(1.4)$

$4.6(1.0)$

2.47

$.024 *$

Total \# of Payments

Total Cost of Loan

$6.3(1.1)$

$5.2(1.3)$

2.33

$.016 *$

$5.1(1.3)$

$4.4(1.3)$

3.79

$.023 *$

Physical Layout

\section{Commercial Loan}

Competence of Loan Officers

$.025 *$

Location of Loan Approval Authority

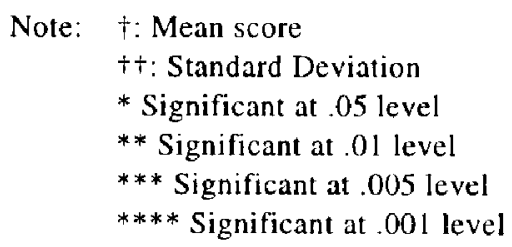

\section{Conclusions and Recommendations}

The implementation of quality initiatives should begin with defining customer needs and preferences, and the respective quality dimensions for multiple targets and market segments, since measuring service performance per se is not as meaningful as measuring performance relative to customers' expectations. Measurement of customers' expectations of banking services provides a frame of reference for banks' assessment of their service quality. Management's first step in planning quality enhancement programs, then, is to survey customer quality criteria. This research focused on two types of loan products, installment and commercial loans, and measured the perceived importance of customer and banker groups on 19 quality dimensions to investigate the consistency between the marketing and operations functions of community banks. 
With respect to the perceived importance of loan service quality attributes by customers and bankers groups, some major findings and recommendations are as follows:

1. For each of the types of loan products, both the customer and banker groups consider the five dimensions of credibility, courteous service, competence of loan officers, and reliable service as the most important. All of the five dimensions are related to functional quality (processing and delivery of loan service) rather than technical quality (loan product characteristics). This finding parallels with that of Johnston (1995), in which he found that the top ten determinants, in terms of frequency of mention, are concerned primarily with the intangible aspects of staffcustomer interface (reliability, availability, responsiveness, and care). This finding can be particularly evident at a time when all competing banks have reached technological and pricing parity because they are searching for high quality through focusing on the interaction between customers and employees. It is essential that bank management produce strategic plans and tactics which take all five of these dimensions into account.

2. With respect to installment loans, both of the groups evaluated the 19 dimensions on a level between "important" and "extremely important." However, the mean scores for the customer group on all of the 19 attributes are higher than those for the banker group. This suggests that customers' expectations for installment loan services are more demanding than bankers' perceptions of the service. Bankers are encouraged to conduct reviews of their operations which might allow their firms to be more competitive in responding to these dimensions.

3. As for commercial loans, fewer quality dimensions were perceived by the two groups as lying between "important" and "extremely important" than was the case for installment loans. Specifically, both of the groups mentioned the attributes of the number of payments, high traffic and access location, and physical layout as "not important." It seems that business customers place their emphasis on fewer dimensions than do individual customers in evaluating loan service quality. This suggests that bankers should focus specifically on these dimensions in quality control efforts.

The MANOVA tests indicate substantial differences between the two groups on the 19 loan service quality attributes. This suggests possible inefficiencies both in performing one of the important marketing functions in banks: listening to customer needs and preferences, and in linking the chosen marketing strategies to those of operations functions. By continually developing various intelligence gathering approaches such as service satisfaction surveys of customers following a service encounter, focus group interviews, and new, declining, and lost-customer surveys, banks can gain understanding on what customers demand and 
their changing preferences. Particularly, when utilizing customer expectation and satisfaction surveys, it is recommended that survey questionnaires be developed internally and tailored to each market or product segment, rather than employing standard survey questionnaires generated by an independent research agency or consulting firm. This will permit effectively meeting or exceeding customers' unique needs for each market or product segment. Customized measuring devices will permit unique assessments of the needs of each bank's clientele.

Once customer needs are identified, efforts should be undertaken to effectively meet those needs through well-coordinated operations functions. By employing the QFD (Quality Functions Deployment) technique, which is a means of integrating customer needs into new product development and aiding in developing marketing and operations strategies, coordinated marketing and operations strategies are likely to be implemented (Reed et al., 1996). Further, banks can deliver appropriate services to their customers in an effective manner only through effective training programs. A growing trend is to require managers, by acting as coaches, to conduct one-on-one service quality training with their employees at the workplace (Morrall, 1995). Athanassopoulos (1997) has noted, in his empirical study, that branches with highly trained personnel who are capable of responding to service queries can exert a positive effect on the sales of loans. Further, he contends that this indicates the importance given by the customers to those banking operations which require human judgments. Hence, carefully conceived training programs should be created, closely supervised, and monitored for effectiveness.

Further, vertical teamwork between top management and low-level employees, and horizontal-cross-functional teams (i.e., teamwork between the front and back offices) play a pivotal role in satisfying customers without undue bureaucracy and communication barriers between levels in banks. For example, although service quality is largely determined by the employees who directly interact with customers, their performance can be greatly influenced by cooperation from backroom workers and other support systems. Integrated teamwork between the various levels in the organizational hierarchy and within multi-functional teams can be obtained through effective communications between the members of the organization and well-conceived training programs. These efforts will increase the probability of a well-coordinated program that focuses directly on customer needs.

Finally, two-tailed t-tests for each of the two product types revealed dissimilarities for individual service quality dimensions. These tests identify the attributes where the greatest between group disagreement took place. Particularly, in the case of installment loans, there are highly significant gaps between customer and banker groups on particular dimensions, such as interest rate, choice of loan duration, relationship banking, and total cost of loan. Bank managers are well-advised to analyze these particular dimensions and attempt to determine why there is such substantial disagreement and how the views of the two groups can be brought 
into a degree of conformity needed to forge a coordinated marketing and operations strategy. Further understanding of customer preferences is important if the bank is to be in a position of competitive advantage.

\section{References}

Amsden, R. T., Ferratt, T. W., \& Amsden, D. M. (1996). TQM: Core paradigm changes. Business Horizons (Nov./Dec.), 6-14.

Armistead, C. G. (1990). Service operations strategy: Framework for matching the service operations task and the service delivery system. International Journal of Service Industry Management, 1 (2), 6-17.

Athanassopoulos, A. D. (1997). Service quality and operating efficiency synergies for management control in the provision of financial services: Evidence from Greek bank branches. European Journal of Operational Research. 98 (2), 300-313.

Berry, L. L., Parasuraman, A., \& Zeithaml,V.A. (1988). The service-quality puzzle. Business Horizons (Sep./Oct.), 35-43.

Bird, A. (1993). One bank's approach to total quality management. The Bankers Magazine (May/June), 63-68.

Boaden, R. J. \& Dale, B. G. (1993). Managing quality improvement in financial services: A framework and case study. The Service Industries Journal. 13 (1), 17-39.

Cowling, A. \& Newman,. K. (1995). Banking on people: TQM, service quality, and human resources. Personnel Review, 24 (7), 25-40.

Cronin, J. J. \& Taylor, S. A. (1992). Measuring service quality: A reexamination and extension. Journal of Marketing 56, 55-68.

Dean, J. W. \& Bowen, D. E. (1994). Management theory and total quality: Improving research and practice through theory development. Academy of Management Review, 19 (3), 392-418.

DeSouza, G. (1989). Now service businesses must manage quality. The Journal of Business Strategy (May/June), $21-25$.

Dotchin, J. A. \& Oakland, J. S. (1994). Total quality management in service - part 2: Service quality. International Journal of Quality \& Reliability Management. 11 (3), $24-42$.

Easton, G. S. \& Jarrell, S. L. (1998). The effects of total quality management on corporate performance: An empirical investigation. Journal of Business, 71 (2), 253-307. 
Eskildson, L. (1995). TQM's role in corporate success: Analyzing the evidence. National Productivity Review (Autumn), 25-38.

Flynn, B. B., Schroeder, R. C., \& Sakakibara, S. (1995). The impact of quality management practices on performance and competitive advantage. Decision Sciences, 26 (5), 659-691.

Gronroos, C. (1983). Innovative marketing strategies and organization structures for service firms. In L. L. Berry, G. L. Shostack, \& G. D. Upah (Eds.). Emerging Perspectives on Services Marketing. (pp. 9-21). Chicago: American Marketing Association. $36-44$.

Hakserver, C. (1996). Total quality management in the small business environment. Business Horizons (March-April), 33-40.

Hendricks, K. B. \& Singhal, V. R. (1997). Does implementing an effective TQM program actually improve operating performance? Empirical evidence from firms that have won quality awards. Management Science. 43 (9), 1258-1274.

Johnston, R. (1995). The determinants of service quality: Satisfiers and dissatisfiers. International Journal of Service Industry Management, 6 (5), 53-71.

Lengnick-Hall, C. A. (1996). Customer contributions to quality: A different view of the customer-oriented firm. Academy of Management Review, 21 (3), 791 -824.

Mefford, R. N. (1993). Improving service quality: Learning from manufacturing. International Journal of Production Economics, 30, 399-413.

Moore, S. A. \& Schlegelmilch, B. B. (1994). Improving service quality in an industrial setting. Industrial Marketing Management. 2, 83-92.

Morrall, K. (1995). Building the bank on total quality management. Bank Marketing 27 (3), 64-68.

Parasuraman, A., Zeithaml, V. A., \& Berry, L. L. (1985). A conceptual model of service quality and its implications for future research. Journal of Marketing. 49, 41-50.

(1988). SERVQUAL: A multi-item scale for measuring consumer perception of service quality. Journal of Retailing. $64,12-40$.

Reed, R., Lemark, D. J., \& Montgomery, J. C. (1996). Beyond process: TQM content and firm performance. Academy of Management Review, 21,173-202.

Rivers, D. B. (1993). Harnessing the power of TQM. Bank Marketing, 25 (6), 35-39. 
Ross, G. R. (1995). Interpersonal stress reactions and service quality responses among hospitality industry employees. The Service Industries Journal, 15, 314-331.

Roth, A. V. \& Jackson, W. E. (1995). Strategic determinants of service quality and performance: Evidence from the banking industry. Management Science. 41 (11), 17201733.

Saunders, P. M., Scherer, R. F., \& Brown, H. E. (1995). Delighting customers by managing expectations of service quality: An example from the optical industry. Journal of Applied Business Rescarch, 11, 101-109.

Shetty, Y. K. (1987). Product quality and competitive strategy. Business Horizons (Sep./ Qct.], 46-52.

Tucci, R. (1997). First Chicago employees give retail banking a 'workout'. National Productivity Review, 17 (1), 25-32. 


\section{Appendix}

Both bankers and loan customers were asked to evaluate each of the 19 service quality attributes for commercial and installment loans. The 19 service criteria employed in the survey include: the total cost of the loan (principal, interest, fees); interest rate (equivalent APR); amount of security (deposits, assets, down payment); choice of loan duration; points (front end fees); total number of payments; competence of loan officers (skill and knowledge); credibility, trustworthiness, honesty of bank personnel; amount of required documentation (minjmum paperwork); relationship banking conduct (non-intimidating, behavior towards customer, seeking long term banking relationships); courteous service (politeness, respect, friendliness); location of loan approval authority (centralized, decentralized, or other); loan processing time (time needed to get approval); responsiveness to customers (prompt problem solving and provision of other customer requested assistance); reliable service (consistent error free service); communications (informing customers clearly and without change from loan application to end of loan); appearances (grounds, furnishing, personnel); high traffic and accessible location; and physical layout (access to parking, loan office privacy). A seven-point Likert scale ranging from $1=$ no importance to $7=$ extreme importance was used for the measurements. For example, the survey request on commercial loans to which bankers responded was "Please circle the response that best indicates how important each service quality criteria is to attracting and to keeping eligible commercial loan customers." The survey request on the same loan product directed to customers was "Please circle the response that best indicates how important each criteria is in evaluating service quality for your commercial loan."

Dr. Minjoon Jun is an Associate Professor in the Management Department at New Mexico State University. He holds a Ph.D. in Operations Management from the Georgia State University. His research interests include total quality management, service operations management, supply chain management, and operations strategy.

Dr. Robin T. Peterson is Norwest Distinguished Professor at New Mexico State University. He holds a Ph.D. in Business Administration from the University of Washington. He has written articles and books in the fields of marketing and management.

Mr. George A. Zsidisin is a Doctoral Candidate in Supply Chain Management at Arizona State University. His research interests include supply risk, service quality, and environmental concerns that impact the supply chain. 
Dr. Bonnie F. Daily is an Associate Professor in the Management Department at New Mexico State University. She holds a Ph.D. in Engineering Management from the University of Missouri-Rolla. Her research interests include group decision support systems, quality management, and environmental management. 